\title{
O International Institute do Teachers College, Columbia University, como epicentro da internacionalização do campo educacional ${ }^{1}$
}

The International Institute of the Teachers College, Columbia University, as the epicenter of internationalization in the educational field

El Internacional Instituto del Colégio de Profesores, Columbia University, como epicentro de la internacionalización del campo educacional

MIRIAN JORGE WARDE ${ }^{2}$

\section{Resumo:}

Este artigo aborda o Teachers College da Columbia University quando se transformava no epicentro da internacionalização do campo educacional ao mesmo tempo que contribuía decisivamente para a sua constituição. Em 1923, o Teachers College criou o International Institute que passou a acolher número de crescente de estudantes e líderes estrangeiros seja como estudantes seja como autores de ensaios e pesquisas publicados no periódico Educational Yearbook aqui focalizado.

Palavras-chave: Teachers College, Universidade de Columbia, internacionalização, campo educacional

\footnotetext{
${ }^{1}$ Trabalho desenvolvido com apoio do CNPq: bolsa produtividade em pesquisa sênior.

2 Doutora em Filosofia da Educação pela Pontifícia Universidade Católica de São Paulo - Professora Titular da Pontifícia Universidade Católica de São Paulo. Professor Visitante Sênior do Programa de Pós-Graduação em Educação Universidade Federal de São Paulo, Campus Guarulhos. Pesquisador sênior do CNPq. Áreas de pesquisa e ensino: História da Educação e da Infância no Brasil e História da Educação e da Infância nos Estados Unidos. E-mail: mjwarde@uol.com.br
} 


\section{Abstract}

This article is about the Teachers College at Columbia University which became the epicenter of the internationalization of the educational field meanwhile such institution contributed decisively to the constitution of that field. In 1923 the Teachers College established the International Institute which started to welcome an increasing number of foreign students and leaders either as students or as authors of essays and studies published in the journal Educational Yearbook, the focus of this article.

Keywords: Teachers College at Columbia University, International Institute, internationalization, educational field

\section{Resumen:}

Este artículo aborda o Teachers College da Columbia University cuando se trasnforma en el epicentro de la internacionalización del campo educacional al mismo tiempo que contribuía decisivamente para su constitución. En 1923, el Teachers College creó el International Institute que pasó a acoger número creciente de estudiantes y líderes, sea como estudiantes, sea como autores de ensayos e investigaciones publicados en el periódico Educational Yearbook aqui focalizado.

Palabras-clave: Teachers College, Universidad de Columbia, internacionalización, campo educacional 


\section{Introdução}

O Teachers College da Universidade de Columbia (TC) adquiriu, ao longo dos anos 1920, feições bastante distintas das que tivera após sua criação em 1887. Os seus reordenamentos estruturais começaram na segunda metade dos anos dez, alterando os formatos dos cursos, as diplomações, os títulos e os departamentos, além da criação de dois institutos. Essas mudanças foram indutoras da constituição de uma nova clientela distinta em relação àquela das primeiras décadas de funcionamento. Por outro lado, não se registram planos institucionais destinados à mudança na composição dos professores e instrutores; no entanto, quer pela aposentadoria de alguns quer pelas novas contratações que se fizeram necessárias, modificações ocorreram nesse âmbito, e não foram de menor importância.

Aquelas alterações operaram no sentido de, em curto prazo, reduzir a demanda constituída de estudantes egressos do ensino médio, mediante a elevação dos requerimentos de matrícula em todas as modalidades de cursos; com isso, a faixa etária da clientela foi elevada, aumentando o número de alunos com experiências profissionais prévias no campo da educação, não apenas na docência, mas especialmente em outras funções ligadas à inspeção, à direção e correlatos. Ao provocar essas mudanças, o TC induziu o aumento considerável de estudantes interessados em pesquisa e nos títulos de Master of Arts (M.A.) e Philosophice Doctor $(\mathrm{PhD})$; dentre eles, muito estrangeiros.

Quanto às alterações nos percentuais relativos à presença masculina e feminina entre os estudantes, os relatórios oficiais ressaltam, bem como as narrativas institucionalizadas, que, como decorrência das mudanças induzidas, teria crescido a presença masculina, enquanto que os ingressos femininos se reduziam, não porque um determinasse o outro, mas porque, uma vez alterado o perfil da clientela nos demais aspectos - em particular, a elevação dos requerimentos de ingresso, a tendência teria sido a redução até o desaparecimento daquela primeira e dominante clientela composta de moças recém-egressas do ensino médio.

No mesmo sentido das demais iniciativas, o TC organizou uma série diversificada de cursos cujos currículos estavam pautados no princípio da profissionalização do pessoal destinado às atividades educacionais, com relevo às escolares; na linha da profissionalização, ganhavam destaque não apenas os cursos que se propunham a elevar o nível de qualificação de professores, mas os que preparavam quadros para o exercício de funções de comando, de 
direção, de inspeção e equivalentes. A ênfase, entretanto estava sendo posta na profissionalização, da qual não decorria, necessariamente, ênfase na especialização; a título de exemplo: as atividades de pesquisa não estavam correlacionadas às funções que o estudante exercia ou pretendia exercer; o que se distinguiam eram os tipos e os níveis de pesquisa pertinentes às funções; além disso, nada indica que a nova estrutura dos cursos estivesse pautada na separação entre docência e outras funções em que o magistério se desdobrava à época. Por certo, que a correlação positiva entre profissionalização e especialização foi sendo estabelecida no campo educacional, como em todos os campos de atividades, até se confundirem, mas isso não estava inscrito na agenda do TC naqueles tempos, seja como princípio seja como meta ${ }^{3}$.

Ainda como partes das mudanças foram criados, em 1921 e em 1923, respectivamente, o Institute of Educational Research ${ }^{4}$ e o International Institute. Com o Instituto Internacional, a clientela do TC ganhou mais um estímulo para ter seu perfil redesenhado, posto que a partir daí começaram a chegar a cada ano letivo centenas de estudantes oriundos de outros países. Entre eles, os primeiros brasileiros que ingressaram no TC por meio daquele Instituto.

As memórias e histórias nascidas internamente ao TC dão como certo que os tempos eram em tudo muito difíceis, em todos os sentidos: sequelas da guerra, levas de imigrantes, lutas operárias, ganância dos tubarões, Depressão Econômica e outros fatores negativos. No entanto, os tempos para o TC teriam sido especialmente vantajosos; tudo parecia somar a favor da sua consagração como centro nacional da constituição da educação como campo acadêmico e, por decorrência, da qualificação do magistério. Naquele momento, as condições teriam sido muito propícias para que o TC também se tornasse o epicentro do processo de internacionalização do campo em constituição, que já havia sido desenhado nos Estados Unidos com vocação para a internacionalidade.

\footnotetext{
${ }^{3}$ Cremin, Shannon e Towsend afirmam que um dos passos mais radicais na direção da elevação do nível do TC foi dado em 1925 quando o curso de graduação de quatro anos da School of Practical Arts foi eliminado, o que colocou a School no mesmo status da School of Education. EM 1926, "todo o curriculum não-profissional de graduação foi abandonado" $(1954$, p. 75$)$

${ }_{4}^{4} \mathrm{Na}$ reunião dos curadores do Teachers College, realizada na quinta-feira dia 10 de fevereiro, foi criado um Instituto de Pesquisa Educacional para promover o estudo científico da educação em colaboração com os vários departamentos da faculdade e com outras instituições interessadas em investigação e pesquisa. " O Instituto compõe-se de três divisões: “ (1) Divisão de Psicologia Educacional) com o Professor Edward L. Thorndike como diretor, (2) Divisão de experimentação escolar, com o professor Otis W. Caldwell como diretor, (3) Divisão de Estudos de Campo, com Professor George D. Strayer como diretor" (COLLEGE NEWS AND DEPARTMENTAL NOTES, 1921, p. 259). Em curto tempo, a Divisão de Psicologia Educacional, sob o comando de Thorndike, foram alçados à condição de epicentro não só das outras divisões que compunham o Instituto, mas em relação a tudo o que dissesse respeito à pesquisa educacional no TC; isso quer dizer, uma enorme concentração de recursos financeiros que haviam começado com a soma de US $\$ 1,870,582.00$ para o ano fiscal 1921-1922.
} 
Com a educação para a democracia fornecida em casa, o College avançou na direção da educação para o internacionalismo. Recorde-se que no fundo das tradições do Teacher College estavam as raízes dos contatos internacionais [...]. Estudantes estrangeiros sempre foram bem recebidos no College e seu número tem constantemente aumentado. Em 1923, havia 265 desses estudantes de 42 países. Sua orientação, cuidado e bem-estar geral tinham se tornado um problema considerável, e a necessidade de provisão especial para eles tinha-se tornado cada vez mais premente. Na busca de uma solução para o problema, o trustee V. Everit Macy, amplamente viajado e especialmente interessado na boa vontade internacional, trouxe a sua influência como apoio (CREMIN, SHANNON, TOWSEND, 1954, p. 73).

Muitas outras histórias e memórias construídas sobre o TC dão por certo de que ali estava, se não a melhor, uma das melhores expressões do que pelo mundo ocidental se estava procurando produzir a respeito de educação e pedagogia. Os livros, os artigos, os materiais pedagógicos, os relatórios de pesquisa, os próprios periódicos mantidos pela instituição davam incessantes provas que dali estava saindo o novo, o científico, o moderno desejado para a educação e a pedagogia ${ }^{5}$.

Não por qualquer qualidade intrínseca que se pudesse asseverar, mas pelo que representavam à época, os trabalhos laudatórios de alemães, ingleses e franceses às grandezas acadêmicas norte-americanas alimentavam as pretensões do TC, posto que nascidos em ambientes culturais tradicionalmente autocentrados, sobre os quais os demais países já haviam cantado a solidez da formação superior, as qualidades educacionais ou os avanços das proposituras pedagógicas em todos os níveis de ensino. Os educadores norte-americanos, desde começos do século XIX, os haviam tomado como termos para comparação de suas próprias iniciativas educacionais; embora, como referente, nenhum tenha se aproximado ao que a Alemanha representou para os Estados Unidos no campo intelectual e na organização das instituições educacionais, pelos menos até começos do século XX. Lá para os anos de 1920, a mudança dos vetores já era bastante visível.

Entre as qualidades consideradas distintivas do TC, destacam-se duas interligadas: a) o TC estaria realizando exatamente o que se esperava dos estudos produzidos no âmbito acadêmico: que dessem fundamento às práticas pedagógicas para as quais há muito não se aceitava as regras da rotina, mas, também, não se queria os riscos da improvisação e b) o TC

\footnotetext{
${ }^{5}$ O TC mantinha desde 1900 o periódico Teachers College Record, que permanece em circulação até os dias; atuais.
} 
reunia um número considerável de professores cujas produções representavam o melhor cartão de visita da Instituição e o seu maior atrativo. Alguns deles, pessoalmente, ou através dos seus escritos - em inglês ou nas primeiras traduções para outras línguas - já haviam entrado em circulação em diversos países, constituindo-se, assim, dois importantes veículos de afirmação da internacionalidade do campo.

Com a criação o Instituto Internacional, em 1923, o número de estudantes estrangeiros aumentou vertiginosamente, com oscilações nos períodos de crises nacionais ou internacionais. Com isso, a repercussão dos trabalhos produzidos no âmbito do TC e a fama dos seus professores só tenderam a crescer internacionalmente ${ }^{6}$.

$\mathrm{Na}$ propaganda que o mentor e diretor do Instituto, Paul Monroe, desencadeou, com a ajuda especial do também professor do TC, Isaac Kandel, conferia-se grande destaque ao fato de o Instituto Internacional contar com recursos financeiros para apoiar, mediante bolsas, os estudos dos alunos estrangeiros; ter condições de protegê-los durante o tempo de permanência na instituição oferecendo-lhes as residências do próprio TC e, no caso das mulheres, oferecer uma residência organizada como clube de convívio, que, enquanto lá residissem, podia ser organizada como sucedâneo do lar, de modo a, para sossego das famílias, funcionar tanto para fins de compensação afetiva como para fins de controle das condutas.

À Fundação Rockefeller, que por contrato original financiaria o Instituto Internacional por dez anos, Paul Monroe prometera desenvolver levantamentos sobre a situação da educação nos mais diferentes países, de sorte a produzir um corpo de informações que sustentasse estudos de natureza comparada, bem como a realizar surveys que produzissem dados em séries, passíveis de serem periodicamente repetidos em cada país, também para fins comparativos. Assim, Monroe revelava como o TC estava especialmente interessado em que muitos estudantes estrangeiros chegassem para estudar o que de melhor aquele College tinha a oferecer da educação e da pedagogia norte-americana, estimulando, ao mesmo tempo, que eles fizessem da situação educacional dos seus países o objeto das suas pesquisas.

No que tange a cada estudante, as promessas incidiam sobre o que cada um poderia, no seu retorno ao lugar de origem, introduzir de melhor, de mais moderno, de mais fundamentado em matéria de educação. Ao se reportarem diretamente aos governos, os representantes do Instituto Internacional não prometiam apenas fazer daqueles estudantes

\footnotetext{
${ }^{6}$ No ano letivo de 1926-27, o número de estudantes estrangeiros aumentou para 457, e os primeiros diplomas especiais como Professor em Escolas Estrangeiras e Supervisor em Escolas Estrangeiras foram concedidos (CREMIN, SHANNON, TOWSEND, 1954, p. 75).
} 
excelentes profissionais e dirigentes da educação para os seus países; colocavam o TC - e em alguns casos, a Universidade de Columbia inteira - à disposição, como interlocutor permanente, fonte de dados e informações regulares e atualizadas, assessoria para reformas; em suma, o que as duas partes considerassem necessário e desejável.

Este artigo aborda o International Institute do Teachers College da Columbia University e seu periódico, o Educational Yearbook, como epicentro da internacionalização do campo educacional entre guerras,

\section{O International Institute: constituindo e internacionalizando o campo educacional}

O Teachers College vai se tornar a Meca para onde os olhos dos melhores estudantes de todos os países do mundo irão se voltar. Eu estou ansioso para o momento em que ele [o TC] irá ocupar um lugar de influência na educação internacional semelhante ao que a Universidade de Paris ocupou na Idade Média.(DUGGAN, 1923, p. 2)

Dirigentes e docentes do TC tinham saído do conflito mundial empenhados no projeto que conduziria os Estados Unidos à hegemonia do mundo capitalista: a eles caberia a difusão dos seus valores mais elevados e da sua experiência democrática.

Em discurso ao alunado em fevereiro de 1918, o Dean (Decano) James Earl Russell alerta para as novas condições da América pós-guerra, nas quais a educação passaria a ter uma nova contribuição na construção da cidadania democrática. Segundo ele, as velhas respostas às antigas perguntas sobre o papel da escola estariam vencidas. (RUSSELL, 1918).

Em artigo publicado no ano seguinte, o Presidente da Columbia University, Nicholas Murray Butler conclama ao engajamento de todos na construção de uma ordem democrática tarefa a ser realizada para muito além da fronteira norte-americana. Em Education after the War Butler igualmente enfatiza a educação para a cidadania, mas a transporta para a cidadania mundial, apontando a necessidade do avanço harmonioso das relações internacionais. Três temas, diz ele, precisam ser estudados, em uma educação que efetivamente aprendeu as lições da guerra: "1) Ética, a doutrina da conduta e do trabalho; 2) Economia, a doutrina da ocupação lucrativa; e 3) Política, a doutrina da reconciliação entre os dois e de viver juntos em harmonia e disposição". (BUTLER, 1919, p. 3) ${ }^{7}$.

\footnotetext{
7 “As responsabilidades da cidadania aumentam diariamente e estão sendo multiplicadas pelos efeitos e resultados da guerra. Há uma dupla necessidade, portanto, de formação da juventude de hoje, que são os homens e as mulheres de amanhã, quanto aos princípios fundamentais da boa cidadania e ao conhecimento desses direitos, deveres e oportunidades, nacionais e internacionais, que constituem os elementos da vida organizada no
} 
O International Institute, criado em 1923, resultou, portanto, de um daqueles esforços do pós-guerra empreendidos por lideranças políticas e intelectuais em várias partes do mundo, especialmente nos Estados Unidos, com vistas a instaurar a amizade internacional e o entendimento entre os povos. Nessa empreitada estiveram envolvidos a Columbia University ${ }^{8}$ e o General Education Board (Conselho Geral de Educação) recém-criado por John D. Rockefeller, que garantiu uma subvenção de \$1,000,000 (um milhão de dólares). A direção ficou a cargo de Paul Monroe e William F. Russell, filho do Decano James Earl Russell, se tornou diretor associado (KANDEL, 1923; CREMIN, SHANNON, TOWSEND, 1954; BU, 1997).

A composição do corpo diretivo parece ter sido bastante criteriosa uma vez que os principais nomes tinham já notável envolvimento com estudos internacionais e comparados. Paul Monroe (1869-1947) consta nos documentos relativos ao Instituto como especialista em educação no Extremo Oriente, no Médio Oriente e como auxiliar no desenvolvimento do sistema educacional das Ilhas Filipinas; William F. Russell (1890-1956) é destacado por um estudo da educação na Sibéria e, em 1921, depois de uma viagem à China, pela cooperação em um relatório sobre a educação cristã na China.

Ainda para o comando do Institute foi chamado Isaac L. Kandel (1881-1965), que já trabalhava em íntima colaboração com Monroe $^{9}$, destacando-se pelo ensino e pelos estudos em educação comparada e pelos trabalhos como membro do staff da Carnegie Foundation for the Advancement of Teaching. Compuseram também o staff diretivo, Lester M. Wilson (18851939), professor do TC, e que tinha vindo do ensino nas Universidades de Puerto Rico e de Wisconsin, e da direção da educação no Peru, e Stephan P. Duggan (1870-1950), professor de Educação no City College e Diretor do Institute of International Education da mesma instituição (HALPERN, 1969). Mais tarde, com a expansão do número de alunos estrangeiros, foram incorporados, também: (Richard) Thomas Alexander (1887-1971), professor do TC, nascido na Alemanha para onde retornou diversas vezes, tornando a educação alemã e

mundo. Quantos deputados o Congresso pode ter, qual o tempo de seus mandatos e que remuneração recebem, são informações de ligeira importância comparadas com o entendimento das razões pelas quais um Congresso existe, de seus poderes e deveres e das maneiras e finalidades pelas quais suas funções têm sido realizadas há 140 anos. Como já foi sugerido, uma verdadeira teoria da política complementará e unirá a boa compreensão tanto da ética quanto da economia". (BUTLER, 1919, p. 5).

${ }^{8}$ Dean Russell e o Presidente Butler participaram intensamente nas iniciativas de guerra e do pós-guerra. A outra importante frente aberta no TC para combater os problemas surgidos durante e no pós-guerra foi a instalação de um programa para a formação da cidadania (CREMIN, SHANNON, TOWSEND, 1954).

${ }^{9} \mathrm{O}$ que já se patenteara na organização e publicação dos cinco volumes da Cyclopedia of Education nos anos de 1910 . 
prussiana seu tema principal de estudo; mantinha uma rede de relações fortes com educadores europeus $^{10}$; Milton C. Del Manzo, George S. Counts ${ }^{11}$, e Ruth McMurry. Praticamente todos membros ativos do movimento educacional progressista (progressive education); com a exceção mais flagrante e declarada de Isaac Kandel (BEREDAY, 1966; POLLACK, 1993; NULL, 2007a)

Foi com uma considerável projeção internacional já conquistada, que Paul Monroe deu apoio e foi apoiado por uma rede de relações travadas dentro e fora do país; com essas relações bem articuladas, pode realizar o projeto do International Institute e conquistar aportes financeiros vultosos de instituições filantrópicas que secundaram a Rockefeller Foundation no empreendimento.

Não resta dúvida de que os patrocinadores, diretores e docentes do International Institute of Teachers College tinham uma refinada visão estratégica da luta pela hegemonia internacional na qual os Estados Unidos estavam inteiramente empenhados; mobilizavam com muita destreza o campo educacional naquela direção. Durante toda a gestão do decano James E. Russell parcela dos professores do College vinha se habilitando para falar para plateias nacionais e internacionais e se dedicando a construir sólidas redes intelectuais e políticas, também nas duas esferas.

Em âmbito interno, os diretores e professores do International Institute compunham uma sólida rede de relações com pares lotados em outras instituições e agências. Por meio dessa rede informal, tinham acesso ou controlavam fundos financeiros para pesquisa, bolsas de estudos para alunos norte-americanos e de outros países, bem como associações acadêmicas e equivalentes. Sobre isso diz Glotzer (2000, p. 94):

Líderes reformistas como Charles $\mathrm{H}$. Judd da Universidade de Chicago, Ellwood P. Cubberly da Universidade de Stanford e John Dewey, George Strayer, Paul Monroe e William H. Kilpatrick do Teachers College da Universidade de Columbia construíram uma rede informal, alocando estudantes e colegas em postos-chave de

\footnotetext{
${ }^{10} \mathrm{Um}$ dos nomes mais amplamente conhecidos é o de Adolphe Ferrière.

${ }^{11}$ Todos os nomes citados são de grande importância no e a partir do TC. O de George S. Counts (18891974) merece especial destaque não só por ter sido uma das primeiras e mais influentes lideranças do progressismo educacional, com John Dewey, mas também pelos densos estudos que realizou sobre a educação nos EUA e na Rússia. Além disso, foi de grande importância na formação dos brasileiros que estudaram no TC de Columbia, particularmente Anísio Teixeira (WARDE, 2006). Counts se doutorou na Chicago University, onde também foi professor nos anos de 1910.
} 
universidades como professores e administradores. A rede se entendia para dentro educação pública, com a promoção em cargos administrativos...

Em relação ao resto do mundo, os membros da rede usavam um determinado padrão: quando um convidado estava impossibilitado de atender ao chamado - espontâneo ou induzido - de algum governante ou de alguma universidade de outro país ou, ainda, de associação estrangeira de diversa natureza, indicava alguém da rede. Com isso, instauravamse circuitos de relações internacionais que envolviam desde dirigentes educacionais a professores, pesquisadores, técnicos, consultores e outros, que se tornavam candidatos "naturais" às bolsas de estudo fornecidas por fundações como a Carnegie Corporation ou a Rockefeller Foundation.

Tudo indica que daquela viagem que Monroe fizera ao ainda Império Otomano nos anos dez, resultaram acordos de cooperação que se desdobraram tanto em estágios de estudo de turcos no International Institute, quanto no envio de técnicos, assessores ou consultores norteamericanos para aquela região. E assim se deu com viagem de John Dewey à Turquia em 1924 como consultor do primeiro governo republicano. Quiçá, todas as viagens de John Dewey ao exterior entre fins da Primeira Guerra Mundial e fins da década seguinte tenham se realizado como parte dos roteiros estabelecidos pelos membros daquela rede informal, mas de laços bem cimentados, que, para fins de Columbia University em geral e International Institute em particular tinham Paul Monroe como figura chave, peça de conexão e interconexão entre outras proeminentes figuras de dentro e de fora do TC.

$\mathrm{O}$ objetivo fundamental do Instituto era "discutir e desenvolver um melhor entendimento internacional através de seu corpo discente estrangeiro" (TEACHERS COLLEGE, 1924). Professores e diretores os orientariam a descobrir os seus interesses especiais, auxiliando-os a escolher os cursos, de sorte a reduzir ou se possível eliminar as diferenças em relação aos estudantes americanos nativos. Para tanto, o Instituto introduziria um curso de familiarização dos alunos com o TC e com os Estados Unidos, um curso complementar sobre ideais e instituições norte-americanas, um curso de visita e observação a escolas norte-americanas, um curso sobre a escola rural, e um sobre administração da educação. 
$\mathrm{Na}$ sua maioria, os alunos passavam o primeiro ano assistindo aqueles cursos introdutórios $^{12}$. Para habilitá-los a visitar organizações educacionais e sociais fora de Nova York, o Instituto viabilizava ajuda financeira. Amplos recursos de bolsa de estudos também eram fornecidos, com as fartas doações de V. Everit Macy, um trustee do TC desde a fundação ${ }^{13}$.

Não eram essas atividades, porém, as mais acalentadas no International Institute; a literatura destaca como principais atividades aquelas ligadas ou derivadas de pesquisa e a assistência/assessoria a sistemas escolares estrangeiros. Segundo Cremin, Shannon e Towsend (1954, p. 74), um dos resultados mais evidentes dos trabalhos de pesquisa se patenteiam na International Education Library criada então, reunindo o que seria "uma das melhores coleções de seu tipo no mundo", assim como os muitos relatórios de pesquisa conduzidas por membros dos professores do Instituto em países estrangeiros e os estudos realizados pelos estudantes estrangeiros sob a direção dos professores do TC. Nessa matéria, destacam, como exemplos, as mais significativas produções da instituição:

\footnotetext{
${ }^{12}$ Um currículo especial foi montado para receber os estudantes estrangeiros, "sem objetivo nem intenção de segregá-los, medida que, aliás, anularia um dos valores intrínsecos de sua presença em uma instituição americana...." Também não seria objetivo do International Institute interferir na especialização desses alunos ou em qualquer linha de interesse educacional; a meta seria "estabelecer uma base geral para um estudo mais aprofundado especializado, descobrir interesses especiais, e ajudar na seleção dos cursos apropriados", que possam ir "ao encontro das necessidades especiais do aluno, em uma palavra para colocá-lo em posição de igualdade com o aluno nativo em relação aos cursos regularmente oferecidos pelo College" (KANDEL, 1923, p. $3)$.

${ }^{13}$ Os alunos do International Institute puderam cursar disciplinas, no ano letivo de 1930/1931, oferecidos para a obtenção do grau de Master of Arts, com os seguintes professores: Lester M. Wilson (2 cursos); Isaac L. Kandel; Harold O. Rugg; Arthur I. Gates (3 cursos); Edward L. Thorndike; Davis Snedden; William Heard Kilpatrick; Goodwin Watson; George S. Counts ${ }^{13}$. No ano de 1927/1928 foram oferecidos também 14 cursos: Lester M. Wilson (2 cursos); William Heard Kilpatrick (2); William C. Bagley (2 em cia); Thomas Alexander (3 em cia); Edward S. Evenden (1 em cia e 1 sozinho); George S. Counts; Mabel Carney (2); I. L.Kandel (1). Três nomes não identificados. No histórico escolar de AT consta...duas disciplinas de Filosofia da Educação com W. Kilpatrick (ambas denominadas Phylosphy of Education), duas disciplinas voltadas à formação de professores (Professional Education of Teachers, com Bagley, Alexander e outros, e Reseacrh of Education of Teachers, com os Bagley, Alexander e Evenden); duas disciplinas relativas à administração educacional (Administration of Teachers College, com Evenden, e Principles of educational administration, com Alexander, Mort e Elsbree); duas voltadas ao tema da educação rural (Field work in rural education and rural sociology e Rural education and country life, com Carney e outros) e quatro com perfis diferençados (Educational Psychology - for foreign students, com Wilson, American Educators, com Counts, The economic effect of education, com Clark, European Education, com Kandel e Curriculum: Basic Considerations, com Bonser e outros). Há que se destacar que os nomes dos professores que constam da ficha escolar de Anísio Teixeira, localizada nos arquivos reservados do TC, não coincidem plenamente com aqueles arrolados no catálogo do ano letivo de 1928-1929, bem como os que o próprio Anísio registrou no seu caderno de notas. Não há incongruências entre essas fontes e sim ausências (TEACHERS COLLEGE, 1928/1929). Cabe lembrar que John Dewey era professor da Columbia University no Departamento de Filosofia, mas oferecia classes no TC. Nos últimos anos da década de 1920 ele estava afastado das aulas.
} 
Em 1923 Paul Monroe visitou a Tchecoslováquia e a Polônia, e William F. Russell, Bulgária; em 1924 Monroe estudou a obra do Near East Relief, uma vez que dizia respeito aos 60 mil órfãos e 40.000 crianças semidependentes sob o seu cuidado; no ano seguinte foi fundada a China Foundation for the Establishment of Education and Culture. Entre 1923 e 1977, as pesquisas eram feitas em escolas nas Filipinas, México, Porto Rico, e na zona rural do Leste, do Sul, e região Ocidental da África, enquanto uma pesquisa sobre instalações educacionais para crianças americanas em terras estrangeiras foi completada por Paul Monroe em 1926 após uma viagem através de Japão, Coréia, China, Índia e Europa (CREMIN, SHANNON, TOWSEND, 1954, p. 74-75).

Em artigo de 1923 Isaac Kandel arrola uma série de fatores que teriam dado suporte e ao mesmo tempo teriam justificado a criação do International Institute. Todos eles apontam nas mesmas direções: a criação do Instituto visava tornar sistemáticos e metódicos os estudos dos estrangeiros sobre a educação norte-americana, assim como ampliar e aprofundar os estudos já desenvolvidos pelos docentes do College relativos aos sistemas educacionais de outros países; tornaria também mais eficazes os procedimentos de difusão de padrões educacionais norte-americanos, ao que se acrescentaria o estreitamento dos laços internacionais e a amizade entre os povos (KANDEL, 1923).

$\mathrm{O}$ interesse despertado pela educação norte-americana, desde a publicação de $A$ democracia na América de Tocqueville, teria levado aos Estados Unidos centenas de "investigadores cujos estudos têm sido baseados na observação um tanto superficial, sem uma investigação intensiva sobre os princípios fundamentais sobre os quais se funda a educação americana" (KANDEL, 1923, p. 1). Para o comparatista Kandel, a superficialidade em que a maioria desses estudos incide decorreria das tentativas muito comuns ao observador externo de "interpretar as práticas e métodos de ensino em termos de normas estrangeiras" (KANDEL, 1923, p. 1). Com a criação do TC, os estudantes de fora passaram a ter a alternativa pioneira de investigações "genuinamente científicas" da educação.

Uma nova onda de interesse teria surgido mais recentemente com o reordenamento geopolítico mundial e a criação de novas repúblicas. Com isso, a extensão mais ampla do espírito da democracia que teria se seguido à Primeira Guerra Mundial só estaria servindo para intensificar esse interesse na educação americana e para levar a um reconhecimento universal do que ela tem para contribuir com seu longo período de experimentação, suas realizações, e o seu tratamento científico. 
Com o crescente fascínio despertado, o TC teria chegado aos anos vinte com mais estudantes de pós-graduação vindos de todas as partes do mundo do que estudantes nativos recebidos por muitos anos após a sua criação ${ }^{14}$. Muitos atraídos pelo o que a educação norteamericana teria de mais moderno - como os testes e as medidas psicológicas; outros, atraídos pelo que há nela de mais tradicional, como a capacidade de maior adaptabilidade da escola americana ao problema imediato, à praticidade tanto da teoria quanto da prática de educadores americanos.

Para Kandel, qualquer que fosse o interesse educacional, todos os estudantes do TC seriam influenciados em alguma medida, pelo espírito de democracia, que durante os últimos anos, e especialmente desde a Guerra, estaria movendo os povos, se não os governos, em todo o mundo. Mais ou menos vagamente, todos percebem que a democracia mundial, como também uma democracia nacional, só pode ser alcançada através da educação, e que, embora com muitas imperfeições, os Estados Unidos têm conseguido muito em educação democrática e a tem experimentado por um período mais longo (KANDEL, 1923).

Apesar do grande número de estrangeiros e da proeminência já adquirida em seus países de origem $^{15}$, por muito tempo o TC não teria instituído condições especiais para esses estudantes, que disputavam a atenção com estudantes nativos com melhor formação e experiência. Com o crescimento do número de estudantes estrangeiros e a ampliação das suas necessidades, tornou-se premente ao College criar mecanismos para que os estudantes vindos de fora possam extrair tanto proveito como deveriam dos cursos oferecidos, familiarizando-os

${ }^{14}$ Kandel (1923) informa que as inscrições representam os seguintes países: África do Sul, Alemanha, Armênia, Áustria, Austrália, Bélgica, Canadá, Chile, China, Colômbia, Coréia, Cuba, Checoslováquia, Dinamarca, Equador, Escócia, Filipinas, Índias Ocidentais Britânicas, Inglaterra, França, Grécia, Havaí, Holanda, Índia, Irlanda, Itália, Japão, México, Nova Zelândia, Nicarágua, Noruega, Palestina, Peru, Polônia, Porto Rico, Rússia, Santo Domingo, Sião, Sibéria, Suécia e Suíça.

15 "A importância desse movimento, que já trouxe cerca de dois mil alunos ao Teachers College, pode ser melhor indicado por aquilo que já foi realizado por alunos estrangeiros do Teachers College. Na China, o presidente da mais influente universidade governalmental em Nanking, o vice-reitor da Universidade Nacional de Pequim, o Presidente da Escola Normal Superior em Pequim, o reitor da Universidade de Pequim, com o apoio das instituições missionárias, o Diretor do trabalho educativo da YMCA, o Secretário e Diretor da recémformada National Association for the Promotion of Education, e mais de duas centenas de outros administradores e professores em cargos importantes, todos foram treinados nesta instituição. De forma semelhante, o movimento educacional moderno no Japão, Filipinas, Índia, África do Sul e em outros lugares está sendo profundamente influenciado pelos homens e mulheres que receberam a sua formação aqui. Assim, nas Filipinas, o Sr. Osias Camile é presidente da Universidade Nacional, o Sr. Francisco Benitez é reitor da Faculdade de Educação da Universidade das Filipinas, na Índia, o falecido Dr. TR Pandya era diretor de Baroda College; na África do Sul Dr. CT Loram, que fez um estudo especial sobre a educação do negro neste país, é comissário de assuntos nativos, dois graduados são diretores de escolas normais, três são conferencistas em departamentos de educação de universidades e colleges, e dois são diretores de escolas de high schools; na Austrália Dr. Percival R. Cole, uma ex-instrutora do College, é vice-diretora do Teachers College e professor de educação na Universidade de Sydney, em Newfoundland Dr. Vincent P. Burke é vice-ministro da educação" (KANDEL, 1923, p. 2). 
com os ideais, objetivos, história e bagagem social e política norte-americanos (KANDEL, 1923).

Em suma, a criação do International Institute visaria não apenas a dedicação de uma atenção especial para os estudantes estrangeiros, mas também a realização de investigações e pesquisas de educação em conexão com os demais países. Esses seriam, segundo Kandel, seus objetivos mais imediatos.

Em 1924, William F. Russell pronunciou um discurso ao alunado do TC com o título de Merchants of light, expressão que seria muitas vezes repetida em diferentes circunstâncias, não só pelo seu criador, referindo-se àquela geração "internacionalista" do TC e que levou adiante o International Institute.

O seu tema: o internacionalismo; o problema: as sequelas da guerra, o bolchevismo que assola o mundo há sete anos. O mundo estaria se tornando cada vez menor, e não adianta tentar o isolamento: "não podemos nos manter completamente fora de contato com os nossos vizinhos"; por outro lado, "o internacionalismo tem sido a causa de uma grande parte dos nossos problemas" (RUSSELL, 1924, p. 1).

O discurso de Russell é repleto de metáforas e alusões ao passado de Roma, da Inglaterra da peste negra... e agora, há sete anos, a "quarentena contra o bolchevismo". Russell fala do terceiro centenário de "A Nova Atlântida de Bacon, do seu isolamento, das formas de comércio permitidas pelo seu governante...

Quando o rei proibiu a todo seu povo a navegação a qualquer porto que não estivesse sob sua coroa, no entanto, baixou esse decreto: que a cada doze anos deveriam partir do reino dois navios, designados para várias viagens; que em qualquer um desses dois navios deveria haver uma missão de três dos sábios ou irmãos da Casa de Salomão, cuja tarefa seria apenas dar-nos conhecimento dos assuntos e do estado dos países para os quais foram designados, e especialmente das ciências, artes, manufaturas e invenções de todo o mundo, e, além disso, trazernos livros, instrumentos e amostras de todas as espécies”. [...] o Governante então observa: "Mas como você vê, mantemos um comércio, não de ouro, prata ou joias, nem de sedas, nem de especiarias, nem de qualquer outra mercadoria de matéria, mas apenas da primeira criatura de Deus, que foi a luz, ter a luz, eu digo, do 
crescimento de todas as partes do mundo[...] A esses chamamos Mercadores da Luz".

Por que "mercadores da luz"?

Mercadores da Luz - eles têm exercido o seu comércio por anos. A partir dos ensinamentos de Paulo ao trabalho dos cientistas da época moderna, tem havido um intercâmbio internacional. A Matemática é uma linguagem comum. Os sinais dos elementos químicos e as fórmulas da Física não conhecem fronteiras nacionais. Os ideais de homens bons e verdadeiros são praticamente os mesmos em todo o mundo.

Mercadores da Luz - diariamente, seu comércio cresce mais vivo. Levou milhares de anos para Aristóteles se tornar conhecido ao mundo. O nome para o hemisfério ocidental é América, em vez de Columbia, porque os geógrafos continentais aprenderam sobre as novas descobertas a partir das cartas de alguém que tinha a fama de ter se juntado à quarta viagem de Colombo. A arte da impressão ainda era desconhecida na Bulgária em 1750. No entanto, a insulina, descoberta apenas há alguns meses, está prolongando a vida dos diabéticos em todos os lugares.

Mercadores da Luz - comprador e vendedor lucram mutuamente. Ninguém é enganado. Não há ressentimentos deixados para trás. Em teoria, isso é a verdade de todo o comércio. A suposição dos economistas medievais: se em uma troca uma parte troca ganhou, a outra foi obrigada a perder, [a troca] já não é realizada. Ambos lucram, onde a troca é racional. Se isto é verdade para os mercadores de "mercadoria material", mais verdadeiro o é para Mercadores da Luz.

Mercadores da Luz - semeiam sem sementes de guerra. Nenhum interesse comercial rival segue seu caminho. Nenhuma esfera de influência é exigida. De seus esforços podem vir a compreensão internacional e a boa vontade internacional. Diz-se que é mais abençoado dar do que receber; mas qual é mais abençoado pelo outro, o doador pelo recebedor ou o recebedor pelo doador? Benjamin Franklin desenvolveu a ideia de que os amigos não são tanto aqueles que fazem as coisas para você, como aqueles para quem você faz as coisas. Outros acreditam que os sentimentos bondosos surgem em gratidão pela bondade prestada. Possivelmente ambos estão certos. De qualquer forma, o Mercador da Luz tanto recebe como dá, e, em cada cômputo, deve incentivar a amizade.

Mercadores da Luz -se acreditamos no nacionalismo ou internacionalismo, eles têm o seu lugar. $\mathrm{O}$ seu trabalho tem sido bem 
feito; seu comércio é crescente; rentável tanto para o comprador e o vendedor, não há inimigos são deixados para trás; mas sim que o aumento da compreensão dos semelhantes e que o sentimento mais quente que vêm tanto da gratificação pelo serviço prestado e de gratidão por boas voltas feitas.

E nessa pujante e epopeica narrativa que cobre de heroísmo e tolerância a si e aos seus, Russell inscreve a tarefa do Instituto Internacional:

Foi para estimular esse comércio/troca internacional que o Instituto Internacional de Teachers College foi fundado. Assim como nossos próprios Mercadores da Luz um quarto de século atrás trouxeram às nossas salas a melhor de teoria e prática estrangeira, então novos mercadores estrangeiros têm anos mais tarde vindo como compradores. Apenas alguns vieram em primeiro, em seguida, muitos, até hoje em dia há uma grande comitiva de mercadores do Teachers College, um pouco como uma guilda medieval, cooperando uns com os outros, fieis aos mesmos ideais, dando préstimos em todos os cantos da terra (RUSSEL, 1924, p. 1-5).

\section{Educational Yearbook - o periódico do International Institute}

O periódico anual, Educational Yearbook (EdYearbook ou EdY), foi previsto no contrato firmado com o General Education Board quando da criação do International Institute e é considerado pelos historiadores uma iniciativa de grande impacto nacional e internacional. O seu ciclo de vida teve a duração de 21 números, entre 1924 e 1944. Segundo $\mathrm{Bu}$ (1997), quando terminou a concessão da Rockefeller Foundation em 1938, Kandel pediu continuidade do auxílio para o anuário; não obtendo, dirigiu-se à Carnegie Corporation - para a qual trabalhava como pesquisador - que lhe concedeu U\$10,000, permitindo a continuidade do Educational Yearbook ${ }^{16}$.

A responsabilidade pela edição foi entregue a Isaac Kandel que, de fato, por ela respondeu durante todo o tempo de existência. Como editor, Kandel construiu um dos mais

\footnotetext{
${ }^{16}$ Segundo Bu (1997, p. 431-432), o EdY foi o primeiro na sua modalidade, desempenhando, assim, "um papel crucial [...] especialmente nos dias em que a literatura desse tipo era extremamente limitada. Como um pioneiro no campo, o Educational Yearbook teve um impacto mundial em educação comparada e internacional, uma vez que foi distribuído em muitas instituições educacionais fora dos Estados Unidos. Ele também foi fundamental em 1932 na criação de uma publicação semelhante - o Year Book of Education - que foi fundado em Londres por Sir Robert Evans e primeira editada por Lord Eustace Percy”.
} 
completos compêndios sobre a educação em todo os continentes e em um grande número de países então existentes. Se um impresso periódico mereceria à época a denominação de enciclopédia universal de educação, esse seria o caso do anuário mantido com recursos do International Institute do qual foi o órgão impresso. Ao Educational Yearbook (EdYearbook ou EdY) caberia também a denominação de maior cartografia da educação, pois que compõe um conjunto organizado, sistemático, de mapas temáticos sobre a educação guiados por critérios certeiros dos assuntos que todos os países igualmente deveriam considerar relevantes e urgentes; escalona os índices de atraso e de inovação dos sistemas e das instituições; classifica o ensino pelo alcance do atendimento, pela formação dos docentes, pelos níveis de financiamento, pelas modalidades e graus de ensino ofertados.

A distribuição dos assuntos e a frequência com que os países aparecem permitem algumas inferências sobre as escolhas efetuadas pelo editor, mas dificilmente permitiriam afirmar com segurança o conjunto dos interesses estratégicos envolvidos, incluídos o International Institute a agência financiadora, Fundação Rockefeller, e outras colaboradoras, e ainda o governo norte-americano. É provável que a distribuição e a frequência referidas tenham resultado de uma combinação de fatores que vão de algumas motivações episódicas até intricadas motivações políticas de longo alcance. O limite do que pode aqui ser inferido é dado pelas informações reunidas no EdY, o espectro de assuntos e de países abordados, os enquadramentos analíticos e estatísticos utilizados, só para citar alguns especialmente relevantes (KANDEL, 1924).

O mapa geopolítico que se pode extrair dos 21 volumes do EdY é impressionante, porque recobre um período em que a maioria dos países estava sendo politicamente redesenhada. Os números do anuário de 1924 a 1944 ecoam, no mínimo, a Primeira Guerra Mundial, a Revolução Russa, a dissolução do Império Otomano, as redefinições do Império Britânico, e a Segunda Guerra Mundial que começou a ser gestada e estava em curso enquanto o periódico esteve em circulação. Acontecimentos que afetaram todos os continentes, cujas sequelas talvez nunca tenham cessado ${ }^{17}$.

Não há espaço neste artigo para análise de todos os aspectos acima enunciados. Por isso, serão destacados apenas os autores, os países envolvidos e os temas educacionais pautados.

\footnotetext{
${ }^{17}$ Os continentes e regiões recobertos pelo EdY são, aproximadamente: 28 na Europa, 3 na América do Norte, 9 na América Central, 9 na América do Sul, 6 na África, 7 no Oriente Médio, 4 na Ásia e 2 na Oceania.
} 
No Tabela 1, estão todas as matérias distribuídas conforme constam no EdY: por países, outras vezes por blocos de países e continentes; constam também algumas colônias e protetorados, como as Colônias alemãs, italianas, francesas, britânicas, belgas e holandesas, e a Síria sob o protetorado da Inglaterra e o Líbano, da França; em alguns casos, como a Índia, não há qualquer referência ao domínio inglês, assim como o Canadá, a Austrália, a União da África do Sul e outras colônias do mesmo império; assim como a Coréia, que vivia sob o domínio do Japão ${ }^{18}$.

Tabela 1 - Distribuição dos países com maiores frequências no Educational Yearbook

\begin{tabular}{l|l}
\hline País & F \\
\hline \hline Estados Unidos & 32 \\
\hline Inglaterra & 29 \\
\hline França & 28 \\
\hline Alemanha & 23 \\
\hline
\end{tabular}

Fonte: Educational Yearbook (tabela criada por MJW)

Das 378 matérias computadas no EdY, a educação nos EUA ocupa o maior número de artigos $(8,5 \%)$, seguida da Inglaterra $(7,7 \%)$, França $(7,4 \%)$ e Alemanha $(6,1 \%)$, como consta da tabela 1. No total, esses, países somados recobrem 112 matérias (29,6\%). Representam, nitidamente, casos exemplares, padrões a funcionarem como modelos, parâmetros para modelização dos demais. A historiografia da educação norte-americana é farta nas referências à Alemanha, França e Inglaterra, nessa ordem, como fontes de "influências" sobre a educação. Assim sendo, os EUA teriam se realizado como síntese desse primeiro bloco.

Essa hierarquia entre os sistemas de ensino é tácita. Como afirma Kandel na Introdução ao primeiro número, de fato, nenhuma comparação foi explicitamente efetuada; ela seria, certamente, de responsabilidade do leitor. Cada autor teria apresentado "o relatório da educação em seu país à sua maneira, a única limitação que é um plano que foi apresentado a cada um a fim de preservar certa uniformidade em todo o volume" (KANDEL, 1924, s/p).

Se somadas as frequências dos países ou regiões colonizadas, esses índices se elevam enormemente. O caso do Império Britânico é o mais impressionante: são 85 matérias $(22,4 \%$ do total). Por outro lado, após a Primeira Guerra, a presença dos Estados Unidos nos países que compunham o Império Britânico aumentou grandemente - por exemplo, na Austrália,

\footnotetext{
${ }^{18}$ Quarenta e quatro matérias registradas $(11,6 \%)$ não se referem a um país em particular.
} 
União da África do Sul e Nova Zelândia - por meio da criação de instituições escolares ou por meio de assessorias regiamente financiadas por fundações privadas norte-americanas ${ }^{19}$. Assim, o que se flagra nas páginas do EdY é um mundo em processo de transformação estrutural, no qual impérios em derrocada como o Britânico ou recém-desmontados como o Otomano, dão espaço à nova hegemonia norte-americana. Em um e outro caso, o TC, o International Institute e uma parcela considerável do corpo docente da Columbia University esteve presente nesse movimento de internacionalização ${ }^{20}$.

Os países (livres ou colônias) que constam da tabela abaixo constituem um grupo muito heterogêneo, que aparece ao longo do ciclo de vida do EdY por meio de temas variados; no entanto, os países têm em comum iniciativas de renovação, reforma ou criação de sistemas públicos de ensino ao mesmo tempo que ainda sofrem com "problemas" no ensino ou na administração das instituições. Rússia/URSS é o caso típico de criação de todo o sistema escolar; Argentina, Brasil, Chile e México são casos de países onde estão ocorrendo reformas modernizadoras; Itália, por seu turno, está alinhando o ensino ao fascismo.

Tabela II - Distribuição dos países e colônias com frequências intermediárias no Educational Yearbook

\begin{tabular}{l|l||l|l}
\hline País & F & País & F \\
\hline \hline África do Sul & 2 & Suécia & 7 \\
\hline União da África do Sul & 8 & Tchecoslováquia & 7 \\
\hline Austrália & 10 & China & 6 \\
\hline Canadá & 9 & Dinamarca & 6 \\
\hline Terra Nova (Newfoundland) & 1 & Holanda & 6 \\
\hline Brasil & 7 & Nova Zelândia & 6 \\
\hline Índia & 7 & Chile & 5 \\
\hline Japão & 7 & México & 5 \\
\hline Noruega & 7 & Polônia & 5 \\
\hline
\end{tabular}

Fonte: Educational Yearbook (tabela criada por MJW)

\footnotetext{
${ }^{19}$ Não casualmente, União da África do Sul/África do Sul, Austrália, Nova Zelândia, Canadá/Terra Nova, Índia são somadas, o tema central de 45 matérias. Individualmente, a incidência variou entre seis e 10.

${ }^{20}$ Ver sobre a presença de Paul Monroe, John Dewey e outros da Columbia University na Turquia (WARDE, 2013). No EdY o Oriente Próximo e a Turquia em particular são temas de quatro matérias, nas quais a presença de instituições norte-americanas na região constituem o ponto central.
} 
O último grupo é composto de países (livres ou colônias) que aparecem durante o ciclo do anuário de uma a quatro vezes. Esse grupo é ainda mais heterogêneo, pois recobre desde a Bélgica até a Letônia e o Paraguai. Com algumas exceções, como a acima citada Bélgica, além da Áustria e da Suíça, a quase totalidade dos demais poderia representa países-problema em matéria de educação, embora com iniciativas inovadoras importantes ou qualificados sistemas de ensino públicos com a Espanha e a Finlândia.

Tabela III - Distribuição dos países e colônias com menores frequências no Educational Yearbook

\begin{tabular}{|c|c|c|c|}
\hline País & $\mathbf{F}$ & País & $\mathbf{F}$ \\
\hline Bélgica & 4 & Equador & 1 \\
\hline Áustria & 3 & Egito & 1 \\
\hline Bulgária & 3 & El Salvador & 1 \\
\hline Grécia & 3 & Estônia & 1 \\
\hline Hungria & 3 & Guatemala & 1 \\
\hline Irlanda do Norte & 3 & Haiti & 1 \\
\hline Uruguai & 3 & Honduras & 1 \\
\hline Espanha & 2 & Irã & 1 \\
\hline Finlândia & 2 & Letônia & 1 \\
\hline Iraque & 2 & Lituânia & 1 \\
\hline Estado Livre Irlandês & 2 & Malásia & 1 \\
\hline Palestina & 2 & Marroco & 1 \\
\hline Peru & 2 & Nicaragua & 1 \\
\hline Suíça & 2 & Panama & 1 \\
\hline Turquia & 2 & Paraguai & 1 \\
\hline Argélia & 1 & Romênia & 1 \\
\hline Bolívia & 1 & Santo Domingo & 1 \\
\hline Colômbia & 1 & $\begin{array}{l}\text { Sérvia, Croácia, } \\
\text { Eslovênia } \\
\end{array}$ & 1 \\
\hline Coréia & 1 & Síria e Líbano & 1 \\
\hline Costa Rica & 1 & Tunisia & 1 \\
\hline Cuba & 1 & Venezuela & 1 \\
\hline
\end{tabular}

Fonte: Educational Yearbook (tabela criada por MJW) 
Das 378 matérias existentes em todo o ciclo do EdY, 372 são assinadas; 187 autores subscrevem apenas uma matéria, distribuídas por diferentes países, regiões e assuntos. Os demais (46 autores) assinam duas ou mais matérias.

Isaac Kandel reuniu um total de 233 autores no EdY. Dos 46 autores que publicaram mais de uma vez, é elevado o número dos que obtiveram em algum momento do século $\mathrm{XX}$ reconhecimento nacional e, em muitos casos, internacional. Na tabela abaixo constam o número de matérias assinadas por cada um deles, os países onde nasceram ou residiram a maior parte de suas vidas, e os países e temas que abordaram em suas matérias. Com exceção de apenas sete, alguma informação sobre os demais foi possível localizar em algum banco de dados online ${ }^{21}$.

É de supor que Kandel tenha exercido pleno controle sobre o anuário. Assina 37 matérias, entre introduções (21), prefácios (2) e artigos (14). Em cada introdução e prefácio ele se alonga sobre o tema do volume e comenta os artigos incluídos.

Segundo Brickman (1951), Kandel tinha proficiência em 10 línguas estrangeiras. Como editor, ele era responsável por selecionar os colaboradores, planejar os tópicos e outras tarefas costumeiras ao escritória da direção de uma publicação periódica. Em acréscimo, traduzia os artigos dos colaboradores do Alemão, Francês, Espanhol, Português, Holandês e Noruegues, e estava linguisticamente preparado para traduzir ao menos mais quatro línguas.

Mas, ainda que se possa conjecturar o auxílio de assistentes em todo o processo de produção dos volumes, é certo que Kandel prestava à Fundação Rockefeller e demais financiadores do International Institute integral respeito aos compromissos previamente firmados; regra de conduta vigente no campo acadêmico com tanto rigor quanto no campo financeiro. Qualquer deslize, representava perda generalizada de legitimidade.

As informações dispostas na tabela permitem que se infira algum grau de notoriedade nos principais campos de interesse ou de atuação dos autores, já atingida à época do convite para o EdY. O fato de a maioria ter abordado algum tema relativo ao seu próprio país sugere alguma reputação ao menos dentro das suas fronteiras nacionais. Excetuados cinco autores que examinam algum aspecto educacional de outro país que não o próprio, esses confirmam a regra: a escolha se dava por competência reconhecida nacional ou internacionalmente. Por outro lado, a maioria dos autores tratou de um tema direta ou indiretamente associado à sua trajetória intelectual e profissional, e no qual se consagraram.

\footnotetext{
${ }^{21}$ Muitos dos autores foram localizados porque dão nomes a prédios e instituições escolares e universitários, bem como a centros de pesquisa e bibliotecas.
} 
Alguns destaques a respeito dos autores que versaram sobre países que não os seus de origem ou residência. Nucia P. Lodge era assistente de George S. Counts no International Institute onde ele exercia a função de diretor assistente. Com Counts, importante educador progressista e especialista em educação na Rússia e na $\mathrm{URSS}^{22}$, Lodge traduziu do russo livros sobre a educação na URSS de grande impacto nos EUA. Sobre um deles, relata Mickenber (2010, p. 103).

Em 1931, um livro escolar soviético feito para ensinar jovens russos sobre o Plano Quinquenal foi um best seller nos Estados Unidos. New Russia's Primer: The Story of the Five-Year Plan do engenheiro-autor soviético M. Il'in, alcançou o público norte-americano graças a George S. Counts, um educador progressista e professor do Teachers College da Columbia University, que, com sua assistente, Nucia P. Lodge, traduziu o livro do seu original de 930. O livro "tomou a América de assalto". O editor juvenil Ernestine Evans chamou a decisão de distribuir a NRP por meio do Book of the Month Club 'o evento extraordinário do mundo editorial deste ano'. E a revista da National Education Association proclamou, "um tal livro é mais do que significativo. É memorável”.

Charles R. Richards consta em vários bancos de dados como proeminente educador no ramo do ensino técnico e profissional, mas também associado a pedagogias ativas e a renomados pedagogistas como William Kilpatrick e Georg Kerschensteiner. Richards foi presidente da International Society for the Promotion of Industrial Education, fundada em 1906, que tinha em seus conselhos nomes como os de Henry S. Pritchett, President Carnegie Foundation, New York; V. Everit Macy, Chairman Board of Trustecs, Teachers' College, New York.

Sir George Anderson (1876-1943) serviu no Indian Educational Service e ficou a maior parte da sua carreira na Índia. Nasceu na Inglaterra e foi educado no Winchester College no University College de Oxford. Obteve a graduação em 1899, com honra, em História Moderna. Transferido para Índia em 1909, Anderson entrou para o Indian Educational Service e foi nomeado como professor de Inglês e História no Elphinstone College, Bombay. Em 1915, foi eleito Secretário Assistemte do Indian Education Department; em 1917, tornou-se Secretário da Calcutta University Commission e, em 1920, Diretor da Instrução Pública de Punjab. Por um tempo, Anderson como Educational Commissioner do Governo da Índia. Foi

\footnotetext{
${ }^{22}$ Para onde viajou para estudo e observação em diferentes oportunidades.
} 
condecorado com o Companion of the Order of the Indian Empire (CIE) in 1920, nomeado cavaleiro em 1924, e honrado com Companion of the Order of the Star of India (CSI) in 1932. Ele se aposentou do Indian Education Service em 1936.

Anderson escreveu vários livros, incluindo A Short History of the British Empire (1912), British Administration in India (1913), Expansion of India, Christian Education in India (1932).

Humphrey Ernest Bowman (1879-1965) foi educado em Eton e New College de Oxford. Serviu no Ministério da Educação egípcio de 1903 a 1923, com um intervalo da guerra quando esteve na França, Índia e Mesopotâmia. A partir de 1918-20, foi Diretor da Educação no Iraque. Nessa função, acompanhou a Missão Árabe de Nejd e Kuwait à GrãBretanha em 1919. Entre 1920 e 1936 foi Diretor da Educação e membro do Conselho Consultivo na Palestina. Bowman ficou temporariamente no Ministério da Informação em 1939 e esteve entre 1941 e 1945 em um serviço especial no Ministério do Exterior.

Isaac B. Berkson (1891-1975) consta como expressivo pensador norte-americano, judeu, destacado intellectual com produção significativa tanto na educação judaica quanto no progressismo educacional laico. Entre outros, publicou o livro Theories of Americanization, em 1920. Ainda em relação aos demais autores de dois ou mais artigos, há nomes proeminentes, como o de Antônio Carneiro Leão (1887-1966), conhecido educador brasileiro seja pela atuação à frente da instrução pública seja pelos escritos; Ernesto Codignola (1885-1865) foi colaborador de Giovanni Gentile na elaboração da chamada reforma Gentile e um dos fundadores da editora La Nuova Italia; Ernest G Malherbe 1896 -1983, autor de livros acadêmicos, foi Reitor da University of Natal, em Durban, África do Sul, entre 1943 e 1965; Amanda Labarca, nascida Amanda Pinto Sepúlveda (1886- 1975), foi uma destacada professora, escritora, feminista, embaixadora e política chilena. Trabalhou principalmente pela melhoria da situação da mulher na América Latina e pelo sufrágio feminino no Chile; Clarence Edward Beeby (1902 - 1998) foi um educador neozelandês, conhecido como "o arquiteto do sistema educacional neozelandês moderno". Ocupou os mais altos cargos de direção da educação, e serviu também como embaixador da Unesco na França; Sir Cyril M. Norwood (1875 - 1956) foi um educador inglês que serviu como diretor de Bristol Grammar School e Harrow School, bem como foi Presidente do St John's College, de Oxford; Timothy Corcoran (1871 - 1843) estudou em colégios jesuítas e ordenou-se padre. Destacou-se pela atuação e escritos em educação, e exerceu importante papel na preservação da língua e da cultura irlandesa. Fundou revistas acadêmicas como em 1912 a Studies. 
É nítida a vantagem da atração e do apoio a pessoas de maior destaque ou experiência nos meios educacionais locais, o que, aliás, se tornaria padrão nas intervenções culturais norteamericanas, com destaque às educacionais: aquelas pessoas reuniam ou estavam em condições de reunir os dados mais completos e atualizados da situação educacional existente em seus países; com os mestres do International Institute aprendiam a problematizar e a interpretar aqueles dados. A cada estudante estrangeiro correspondia, no mínimo, uma dissertação apresentada ao final dos estudos para obtenção do título, tratando de aspectos da educação de seu país de origem; com isso, ao final de cada ano letivo o International Institute podia reunir a soma mais completa e diversificada de informações sobre a educação em várias partes do mundo.

Tabela IV -Autores que publicaram mais de um artigo no EdY, seus países de origem/residência, temas e países abordados.

\begin{tabular}{|c|c|c|c|}
\hline Autor & $\begin{array}{l}\mathbf{N}^{\mathbf{o}} \text { matérias } \\
\text { assinadas }\end{array}$ & $\begin{array}{l}\text { País de nascimento ou de } \\
\text { residência }\end{array}$ & $\begin{array}{l}\text { País abordado nas } \\
\text { matérias que assina }\end{array}$ \\
\hline Isaac Kandel & 37 & Estados Unidos & Vários \\
\hline Commission française* & 11 & França & França \\
\hline Reinhold Lehmann & 8 & Alemanha & Alemanha \\
\hline Nucia P. Lodge & 7 & Estados Unidos & Rússia/URSS \\
\hline W.H. Perkins & 7 & Inglaterra & Inglaterra \\
\hline A. Carneiro Leao & 7 & Brasil & Brasil \\
\hline E. Codignola & 6 & Itália & Itália \\
\hline Ernesto Nelson & 6 & - & Argentina \\
\hline T. Percy Nunn (Sir) & 5 & Britânico & Inglaterra \\
\hline E.G. Malherbe & 5 & África do Sul & África do Sul \\
\hline W. Carson Ryan & 5 & Estados Unidos & Estados Unidos \\
\hline Charles R. Richards & 5 & Estados Unidos & França \\
\hline Emanuel Lippert & 4 & Tchecoslováquia & Tchecoslováquia \\
\hline B.J. Bergqvist & 3 & Suécia & Suécia \\
\hline C. T. Loram & 3 & África do Sul & Àfrica / África do Sul \\
\hline P.A. Diels & 3 & - & Holanda \\
\hline Percival R. Cole & 3 & Austrália & Austrália \\
\hline George Anderson (Sir) & 3 & Britânico & Índia \\
\hline Felix Pecaut & 3 & França & França \\
\hline R.F.Alfred Hoernle & 2 & União da África do Sul & União da África do Sul \\
\hline Thomas H. Briggs & 2 & Estados Unidos & Estados Unidos \\
\hline W.E. Macpherson & 2 & - & Canadá \\
\hline Arnold E. Campbell & 2 & Nova Zelândia & Nova Zelândia \\
\hline Amanda Labarca & 2 & Chile & Chile \\
\hline C.E. Beeby & 2 & Nova Zelândia & Nova Zelândia \\
\hline Cyril Norwood & 2 & Inglaterra & Inglaterra \\
\hline Dario E. Salas & 2 & Chile & Chile \\
\hline Edmund de S. Brunner (Rev.) & 2 & Estados Unidos & Estados Unidos \\
\hline Einar Sigmund & 2 & Noruega & Noruega \\
\hline Emilio Fournie & 2 & Uruguai & Uruguai \\
\hline Garnet V. Portus & 2 & Austrália & Austrália \\
\hline George S. Browne & 2 & Austrália & Austrália \\
\hline George Sakellariou & 2 & - & Grécia \\
\hline
\end{tabular}




\begin{tabular}{l|l|l|l}
\hline $\begin{array}{l}\text { Humphrey E. Bowman \& } \\
\text { Isaac B. Berkson }\end{array}$ & 2 & Inglaterra/ Estados Unidos & Palestina \\
\hline J.G. Althouse & 2 & Canadá & Canadá \\
\hline Julius Nielsen & 2 & - & Dinamarca \\
\hline Luis Enrique Galvan & 2 & Peru & Peru \\
\hline Maurice Weber & 2 & França & França \\
\hline Mieczyslaw Ziemnowicz & 2 & Polônia & Polônia \\
\hline Paul Barrier & 2 & - & França \\
\hline Rafael Ramirez & 2 & México & México \\
\hline T. Corcoran & 2 & Estado Livre Irlandês & Estado Livre Irlandês \\
\hline V. Fadrus & 2 & Áustria & Áustria \\
\hline W.J. McCallister & 2 & - & Irlanda do Norte \\
\hline William McClelland & 2 & Escócia & Escócia \\
\hline Stoian Omarchevsky & 2 & Bulgária & Bulgária \\
\hline Total & $\mathbf{1 8 5}$ & & \\
\hline \hline
\end{tabular}

Fonte: Educational Yearbook (tabela criada por MJW).

*Commission française pour l'Enquête Carnegie sur les Examens et Concours en France

Isaac Kandel, editor do EdY, era certamente dos mais renomados dentre os autores.

Nasceu na Romênia, de pais ingleses; recebeu sua educação inicial no Reino Unido, bem como seus diplomas de bacharel e mestre, e o certificado de professor. Foi seu professor da University of Manchester, o Sir Michael Sadler, um dos próceres da Educação Comparada, que o orientou a fazer o doutorado no TC da Columbia University. Em 1913, já era nomeado instrutor naquele College; em 1915 se tornou professor associado, obtendo sua plena estabilidade em 1923; em 1947, ganhou o título de professor emérito (POLLACK, 1993). Depois de um tempo de estudo na Alemanha, chegou aos EUA em 1908 para estudar educação comparada e internacional. Em 1910, depois de dois anos, recebeu o Ph.D pela Columbia Univeristy. Sua tese, The Training of Elementary School Teachers in Germany, foi baseada em pesquisa e observações de primeira mão em escolas de formação docente na Alemanha. No mesmo ano, a editora do TC a publicou como livro ${ }^{23}$. Nesse trabalho, Kandel já salienta o que tentaria converter em seu método nos estudos internacionais e comparados: destaca as qualidades positivas da formação de professores do ensino fundamental alemão, mas não a recomenda para adoção.

Nessa direção, Kandel se tornou um dos líderes defensores da tendência de pensamento na educação comparada que se tornou conhecida como "funcionalismo histórico". A idea básica dessa tendência é que os sistemas educacionais não operam no vácuo; são entrelaçados inextricavelmente com outras instituições sociais e políticas, e, por isso, só podem ser compreendidos em seus próprios contextos ou ambientes culturais e históricos. Nessa direção

\footnotetext{
${ }^{23}$ No Training of elementary school teachers in Germany, Kandel escreveu sobre a evolução dos professores alemães a uma classe de profissionais. A luta dos professores elementares era uma batalha contra o obscurantismo e a dominação clerical. As escolas "normais" responsáveis pela formação de professores eram mais vitimizadas pela tradição do que eram outras instituições, que contribuia para a rigidez da educação alemã (BRICKMAN, 1951).
} 
indicada, a Educação Comparada para Kandel podia ser concebida como a continuação do estudo da história da educação no presente.

Para elaborar sua própria perspectiva educacional, Kandel seguiu um conjunto muito específico de orientadores e orientações. Destaca-se, em primeiro lugar, o seu já citado professor britânico, Sir Michael Sadler (1861-1943), famosa autoridade em educação secundária e Educação Comparada, e estudioso do sistema público de ensino britânico ${ }^{24}$.

Kandel menciona Sadler frequentemente em seus escritos relativos à Educação Comparada. Para Pollack (1993), o discípulo aprendeu a olhar esses assuntos através das largas lentes teóricas da "sociologia política de Sadler", segundo a qual era preciso estudar as influências societais sobre a educação como mais importante do que meramente estudar sistemas particulares isoladamente; essa seria a única forma de se entender efetivamente os sistemas educacionais.

Paul Monroe foi outra referência importante para Kandel; com ele estudou e trabalhou em vários projetos de longa duração, por exemplo, assistindo-o na edição da Cyclopedia of Education (BRICKMAN, CORDASCO, 1970) e como editor do Educational Yearbook do International Institute $^{25}$. No âmbito da Educação Comparada, foram muitos os projetos nos quais Monroe e Kandel estiveram conjuntamente envolvidos seja em nome de instituições filantrópicas privadas seja em nome do governo norte-americano. Com Monroe, Kandel aprendeu a importância de estudar a História da Educação, especialmente por sua interrelação com a Educação Comparada.

William C. Bagley (1874-1946), conhecido educador e colega no TC, também foi capital para Kandel estabelecer seu norte teórico. Bagley foi o principal porta voz do chamado "movimento essencialista em Educação", e com ele Kandel defendeu muitas das ideias contra o progressivismo em educação, em defesa da herança cultural, e da centralidade do professor no processo educacional (NULL, 2001, 2007b) ${ }^{26}$.

Embora criticasse abertarmente o progressismo em seus ensaios e artigos acadêmicos, Kandel concordava com muitos postulados do movimento, especialmente aqueles que aplicavam no ensino os mais modernos princípios da Psicologia, mas não aceitava "o zelo

\footnotetext{
${ }^{24}$ Foi condecorado pela coroa britânica em 1919.

${ }^{25}$ De 1909 a 1913 foi editor assistente da Cyclopedia of Education. Durante esse período, ele escreveu muitos artigos numa ampla variedade de tópicos sobre história da educação para a Cyclopedia. Em acréscimo a esses e outros artigos, Kandel escreveu trabalhos históricos tais como An introduction to the study of American education, History of the curriculum, History of secondary educacion e American education in the twentieth century.

${ }^{26}$ Kandel diz que a democracia é enfraquecida consideravelmente quando a cultura dentro de uma nação democrática em particular, especialmente os EUA, dá livre rédea ao individualismo sem ensinar o povo a desenvolver o senso de responsablidade. Esse era um tema recorrente em sua obra.
} 
missionário e falta de tolerância" de muitos dos grandes progressivistas do seu tempo. Criticava a radicalidade com que progressivistas modernos pretendiam romper com o passado projetando o futuro na incerteza. Para Kandel, a disputa estava entre o culto da mudança e da desorganização versus a cultura da permanência (BU, 1997; CHAMBERS, 1969; ) ${ }^{27}$.

Quanto aos assuntos apresentados no EdY, a pauta do primeiro número de 1924 será mantida sem grandes alterações até o volume de 1928: uma série de artigos em torno de temas amplos tais como o sistema educacional em diferentes países, seguida de alguns poucos artigos a respeito de um tema ou problema específico; no primeiro número: "o problema do método". Na primeira leva, o EdY reúne países em diferentes graus de desenvolvimento do sistema de ensino e de governo da administração pública sobre esses sistemas. No que tange ao tópico específico, exemplos dos mais avançados: Inglaterra, Alemanha, Estados Unidos e o movimento europeu da escola nova relatado por um dos seus próceres: Ferrière.

Nesse número, Kandel é claro na condução a uma leitura comparatista: o objetivo é reunir a maior soma de informações e dados estatísticos já compilados em uma mesmo lugar. Os autores seguem praticamente os mesmos parâmetros para descrever a situação das escolas, o desenvolvimento dos graus e modalidades de ensino, o governo da educação, o financiamento do ensino, as estatísticas de ingresso, evasão e conclusão... para citar os aspectos com maior convergência, e que se consagravam na historiografia da educação de autores como Paul Monroe e Isaac Kandel, e que iriam se consagrar, ao menos, na historiografia da educação brasileira.

O segundo volume, repete o formato: um prefácio e uma introdução de Kandel, seguidos de artigos sobre o sistema educacional - em suas diferentes facetas - na Argentina, no Brasil, Chile, Índias Holandesas Orientais, Inglaterra, França e Alemanha, Holanda, Índia e no Japão, Letônia, Nova Zelândia, Escócia, Estados Unidos e Uruguai. O tópico destacado para fechar esse volume é "O problema do currículo da escolar elementar" na Inglaterra, Alemanha e Estados Unidos, os mesmos países exemplares do número anterior.

\footnotetext{
${ }^{27}$ Isaac Kandel escreveu e publicou um vasto número de trabalhos. Elaborou monografias sobre sistemas escolares em países europeus, especialmente da França, Alemanha e Reino Unido sob o patrocínio do Bureu de Educação dos Estados Unidos. Esses trabalhos, publicados como "Buletins" pelo próprio Bureau, entre 1913 e 1919, deram início à reputação de Kandel como uma das principais autoridades do mundo em sistemas educacionais de vários países. Como especialista em pesquisa para a Carnegie Foundation for the Advancement of Teaching de 1914 a 1923, Kandel produziu trabalhos sobre diversos tópicos tais como educação professional, aposentadoria dos professores, sistemas de exames, dentre outros. Em 1918, auxiliou Paul Monroe num estudo autorizado pelo presidente Woodrow Wilson que consistia de traduções de leis e regulamentações administrativas de escolas estrangeiras, para serem consultadas pelo governo dos Estados Unidos. Foi também professor visitante de várias importantes universidades norte-americanas, incluindo Yale, Johns Hopkins e a Universidade da California de 1919 a 1940. Fora dos Estados Unidos, lecionou na Universidade do México em 1927, e no começo dos anos 1930, ofereceu importantes seminários na Universidade de Londres, Harvard e outras. Suas lectures em Londres e Harvard foram publicadas como livros intitulados respectivamente de The Outlook in Education e The Dilemna of Democracy (BEREDAY, 1966; POLLACK, 1993; NULL, 2007a).
} 
O terceiro volume mostra certa variação nos aspectos destacados pelos autores em relação aos sistemas educacionais examinados: mais ênfase no governo da educação ou mais destaque às dificuldades de atendimento ou mudanças decorrentes da conjuntura nacional etc. Mas ainda são os sistemas de ensino que estão na mira do anuário. Dessa vez o tema destacado é "os problemas da educação secundária" naqueles mesmos três países destacados anteriormente.

Em 1927, o quarto volume apresenta o tema dos sistemas educacionais com as mesmas variações do anterior, acrescido de quatro artigos em torno do "problema da formação do professor"; a França é acrescentada à Inglaterra, Alemanha e Estados Unidos. Essa estrutura é mantida no volume de 1928, sendo que o foco dessa vez incide sobre "o problema da educação profissional" nos quatro países de referência, sendo que nos artigos sobre os sistemas educacionais, os Estados Unidos, a Alemanha, a França e a Inglaterra comparecem nesses cinco números iniciais, enquanto os demais países variam. $\mathrm{O}$ anuário consagra a função paradigmática que esses países já exerciam em matéria de educação.

A partir de 1929, há uma alteração na programação do anuário que só seria notifica no ano seguinte, embora não explicada. O volume sexto, de 1929, é pautado em torno do tema "a filosofia subjacente aos sistemas nacionais de Educação", não havendo mais a separação entre um tema geral e um tópico específico. Nesse volume os países contemplados são os quatro constantes e mais o Japão e a Itália. No volume de 1930, o tema comum é "a educação secundária" em quinze países, maioria já contemplada anteriormente, com a ausência pela primeira vez da Alemanha. No ano seguinte, o foco recai sobre a "educação em dependências coloniais". Os volumes subsequentes repetem essa estrutura, tal como se pode ver no quadro abaixo.

Quadro único - Temas apresentados no Educational Yearbook, por países livres, colônias, protetorados.

\begin{tabular}{|l|l|l|}
\hline Ano & Tema geral e específico & Países independentes, Colônias, Protetorados... \\
\hline 1924 & O sistema educacional & $\begin{array}{l}\text { Austrália, Bulgária, Canadá, China, Tchecoslováquia, Inglaterra, } \\
\text { França, Alemanha, Itália, Noruega, África do Sul, Estados } \\
\text { Unidos }\end{array}$ \\
\cline { 2 - 4 } & O problema do método & $\begin{array}{l}\text { Inglaterra, Alemanha, Estados Unidos, Movimento a Educação } \\
\text { Nova }\end{array}$ \\
\hline 1925 & O sistema educacional & $\begin{array}{l}\text { Argentina, Brasil, Chile, Índias Holandesas Orientais, Inglaterra, } \\
\text { França, Alemanha, Holanda, Índia, Japão, Letônia, Nova } \\
\text { Zelândia, Escócia, Estados Unidos, Uruguai }\end{array}$ \\
\cline { 2 - 4 } & $\begin{array}{l}\text { O problema do currículo da } \\
\text { escolar elementar }\end{array}$ & \begin{tabular}{l} 
Inglaterra, Alemanha, Estados Unidos \\
\hline 1926
\end{tabular} O sistema educacional \\
\cline { 2 - 3 } & $\begin{array}{l}\text { Áustria, Inglaterra, Estônia, Finlândia, França, Alemanha, Grécia, } \\
\text { Estado Irlandês Livre, Terra Nova (Canadá), Irlanda do Norte, } \\
\text { Polônia, Suécia, Suíça, Estados Unidos }\end{array}$ \\
\hline
\end{tabular}




\begin{tabular}{|c|c|c|}
\hline & $\begin{array}{lll}\begin{array}{l}\text { Problemas } \\
\text { secundária }\end{array} & \text { da } & \text { educação } \\
\end{array}$ & Inglaterra, Alemanha, Estados Unidos \\
\hline \multirow[t]{2}{*}{1927} & O sistema educacional & $\begin{array}{l}\text { Bélgica, Dinamarca, Inglaterra, França, Alemanha, Hungria, } \\
\text { Iraque, Lituânia, México, Rússia, Sérvia, Croácia e Eslovênia, } \\
\text { Espanha, Turquia, Estados Unidos }\end{array}$ \\
\hline & $\begin{array}{l}\mathrm{O} \text { problema da formação do } \\
\text { professor }\end{array}$ & Inglaterra, França, Alemanha, Estados Unidos \\
\hline \multirow[t]{2}{*}{1928} & O sistema educacional & Inglaterra, França, Alemanha, Palestina, Estados Unidos \\
\hline & $\begin{array}{lll}\begin{array}{l}\text { O problema } \\
\text { profissional }\end{array} & \text { da educação } \\
\end{array}$ & Inglaterra, França, Alemanha, Estados Unidos \\
\hline 1929 & $\begin{array}{l}\text { A filosofia subjacente aos } \\
\text { sistemas nacionais de Educação }\end{array}$ & Inglaterra, França, Alemanha, Itália, Japão, Estados Unidos \\
\hline 1930 & A educação secundária & $\begin{array}{l}\text { Argentina, Austrália, Áustria, Bulgária, Chile, Tchecoslováquia, } \\
\text { Inglaterra, França, Hungria, Itália, Japão, Polônia, África do Sul, } \\
\text { Suécia, Estados Unidos }\end{array}$ \\
\hline 1931 & $\begin{array}{l}\text { A educação em dependências } \\
\text { coloniais }\end{array}$ & $\begin{array}{l}\text { Síria e Líbano, Congo Belga, Colônias Francesas, Colônias } \\
\text { Alemãs antes da Guerra, Marrocos, Argélia, Povos Indígenas } \\
\text { (Geral), Malásia, França, Colônias Italianas }\end{array}$ \\
\hline 1932 & $\begin{array}{l}\text { A relação do Estado com a } \\
\text { Educação Religiosa }\end{array}$ & $\begin{array}{l}\text { Austrália, Bélgica, Canadá (2), China, Tchecoslováquia, } \\
\text { Inglaterra (4), França, Holanda, Alemanha (2), İndia, Itália, } \\
\text { Japão, América Latina, México, Noriega, Escócia, Suécia, União } \\
\text { da África do Sul, Estados Unidos (3) }\end{array}$ \\
\hline 1933 & $\begin{array}{l}\text { Atividades missionárias em terras } \\
\text { estrangeiras e entre os povos } \\
\text { atrasados }\end{array}$ & $\begin{array}{l}\text { África, China, Índia, Japão, Coréia, América Latina, Oriente } \\
\text { Próximo, Vários países (9) }\end{array}$ \\
\hline Ano & Tema geral e específico & Países independentes, Colônias, Protetorados... \\
\hline 1934 & Exames & Rússia Soviética (7), França (12), Alemanha/Terceiro Reich (5) \\
\hline 1935 & Associações de professores & $\begin{array}{l}\text { Argentina, Austrália, Brasil, Canadá, Tchecoslovaquia, } \\
\text { Dinamarca, Inglaterra e Gales, França, Alemanha, Itália, Japão, } \\
\text { Noruega, Polônia, Escócia, Suécia, União da África do Sul, } \\
\text { Estados Unidos (2) }\end{array}$ \\
\hline 1936 & $\begin{array}{l}\text { Os sistemas de ensino } 12 \text { anos } \\
\text { depois: novos problemas }\end{array}$ & $\begin{array}{l}\text { Argentina, Austrália, Brasil, Canadá, Chile, China, } \\
\text { Tchecoslováquia, Dinamarca, Inglaterra, Alemanha, Holanda, } \\
\text { Japão, Nova Zelândia, Noruega, Escócia, Espanha, Suécia, União } \\
\text { da África do Sul, Estados Unidos }\end{array}$ \\
\hline 1937 & $\begin{array}{l}\text { Os sistemas de ensino anos } \\
\text { depois: novos problemas }\end{array}$ & $\begin{array}{l}\text { Austria, Bélgica, Bulgária, Índias Holandesas Orientais, Egito, } \\
\text { Finlândia, Grécia, Hungria, Índia, Irã, Iraque, Estado Livre } \\
\text { Irlandês, Itália, Irlanda do Norte, Palestina, Peru, Polônia, } \\
\text { Romênia, Suíça, Turquia, URSS, Uruguai }\end{array}$ \\
\hline 1938 & O problema da educação rural & $\begin{array}{l}\text { Argentina, Austrália, Brasil, China, Tchecoslováquia, Dinamarca, } \\
\text { Inglaterra, França, Alemanha, Índia, México, Noruega, Estados } \\
\text { Unidos }\end{array}$ \\
\hline 1939 & $\begin{array}{l}\text { O significado de uma educação } \\
\text { liberal no século XX }\end{array}$ & $\begin{array}{l}\text { Argentina, Austrália, Brasil, Chile, Dinamarca, Inglaterra (4), } \\
\text { França, Alemanha/Terceiro Reich, Holanda, Índia, Itália, Nova } \\
\text { Zelândia, Noruega, Escócia, Suécia, União da África do Sul (2), } \\
\text { Estados Unidos (3) }\end{array}$ \\
\hline 1940 & Educação de adultos & $\begin{array}{l}\text { Argentina, Austrália, Brasil, Canadá, Dinamarca, Inglaterra, } \\
\text { França, iTália, México, Holanda, Nova Zelândia, Escócia, } \\
\text { Suécia, União da África do Sul, Estados Unidos }\end{array}$ \\
\hline 1941 & Vários Temas & $\begin{array}{l}\text { Todos artigos assinados por I. Kandel para manter a continuidade } \\
\text { do anuário }\end{array}$ \\
\hline 1942 & $\begin{array}{l}\text { Esforços para } \\
\text { educação }\end{array}$ & $\begin{array}{l}\text { Argentina, Bolívia, Brasil, Chile, Colômbia, Costa Rica, Cuba, } \\
\text { Equador, El Salvador, Guatemala, Haiti, Honduras, México, } \\
\text { Nicarágua, Panamá, Paraguai, Peru, Santo Domingo, Uruguai, } \\
\text { Venezuela }\end{array}$ \\
\hline 1943 & $\begin{array}{l}\text { Ensino superior nos planos de } \\
\text { reconstrução pós-guerra }\end{array}$ & $\begin{array}{l}\text { Austrália, Canadá, Inglaterra (4), Índia, Irlanda, Nova Zelândia, } \\
\text { Escócia, União da África do Sul, Estados Unidos (6) }\end{array}$ \\
\hline 1944 & $\mathrm{O}$ futuro da educação ou $\mathrm{A}$ & Nova Zelândia, Polônia, Tchecoslováquia, Holanda, Inglaterra, \\
\hline
\end{tabular}


Fonte: Educational Yearbook (quadro criado por MJW).

\section{Palavras finais}

Embora não tenha sido a primeira instituição de estudos superiores em Educação a ser criada nos Estados Unidos, o Teachers College da Columbia University é referido na historiografia educacional como decisivo para a configuração do campo, ao início do século $\mathrm{XX}$, e para a trajetória das disciplinas que nele se consagraram ao longo do tempo. Foi, acima de tudo, um dos principais polos de fomento à internacionalização do campo educacional ao mesmo tempo em que se constituia.

A historiografia admite que o TC tenha sido pioneiro na constituição dos ramos da educação comparada e da educação internacional. De fato, foi o International Innstitute que liderou o ativismo internacional por meio da participação direta do corpo docente na reforma dos sistemas de educação estrangeiros e na formação profissional dos estudantes e líderes educacionais estrangeiros. A profícua investigação sobre as sociedades e os sistemas de ensino de outros países ou colônias, e a acumulação de materiais sobre teorias educacionais e práticas realizados pelo International Institute contribuir decisivamente para o TC desenvolver estudos da educação comparada e fomentá-los em outras universidades da América do Norte e alhures. (BU, 1997).

$\mathrm{O}$ TC contou com instrumentos poderosos para operar com vistas à internacionalidade do campo, destacando-se: um corpo de dirigentes e professores internacionalista, disposto a incanssavelmente atravessar territórios e línguas para levar a nova palavra em matéria de educação dos povos, convencidos de que eram, como norte-americanos, seus portadores, e altos investimentos de coorporações/fundações empenhadas na construção da hegemonia dos EUA contra as velhas barbáries e a nova representada pelo bolchevismo.

Aos estudantes de todos os continentes atraídos para ao menos um ano letivo de estudos, os docentes e o staff do TC, responsável pelo o International Institute, pretendeu mais do que conquistar para a reconstrução educacional, a nova sensibilidade para os problemas do entre-guerras, a nova disposição mental para as relações entre as nações; nos estudantes estrangeiros depositaram a expectativa de se engajarem na missão norte-americana de recivilização do mundo; seriam, eles também, mercadores da luz. 
Do conjunto das ações que caracterizam o ativismo internacionalista do International Institute do TC, foi destacado o seu periódico, Educational Yearbook, sobre o qual foram apresentados alguns dos seus elementos estruturantes. Análises mais aprofundadas sobre as suas matérias, bem como sobre sua circulação, serão feitas em novas oportunidades.

\section{Referências}

BEREDAY, G. Z. F. Memorial to Isaac Kandel (1881-1965). Comparative Education, [S.1.], v. 2, n. 3, p. 147-150, 1966

BRICKMAN, W. W. Kandel: International Scholar and Educator. The Educational Forum. [S.1.], v. 15, n. 4, p. 389-412, 1951.

BRICKMAN, W. W., CORDASCO, F. Paul Monroe's Cyclopedia of Education: With Notices of Educational Encyclopedias Past and Present. History of Education Quarterly, [S.1.], v. 10, n. 3, p. 324-337, Aut. 1970.

BU, L. International Activism and Comparative Education: Pioneering Efforts of the International Institute of Teachers College, Columbia University. Comparative Education Review, Chicago, v. 41, n. 4, p. 413-434, Nov. 1997. http://dx.doi.org/10.1096/447463

BUTLER, N. M. Education after the War. Teachers College Record, New York, v. 20, n. 1, p. 1-15, 1919. Disponível em: $<$ http://www.trecord.org $>$ ID Number: 3721 . Acesso em: 2 de dezembro de 2014.

CHAMBERS, G. Michael John Demiashkevich and the Essentialist Committee for the Advancement of American Education. History of Education Quarterly, [S.1.], v. 9, n. 1, p. 46-56, Spring, 1969.

COLLEGE NEWS AND DEPARTMENTAL NOTES. Teachers College Record, New York, v. 22, n. 3, p. 259-259, 1921. Disponível em: < http://www.tcrecord.org> ID Number: 4065. Acesso em: 3 de janeiro de 2016.

CREMIN, L. A.; SHANNON, D. A.; TOWSEND, M. E. A History of Teachers College, Columbia University. New York: Columbia University Press, 1954.

DUGGAN, S. P. American Influence in World Education. Teachers College Record, New York, v. 24, n. 3, p. 204-207, 1923. Disponível em: <http://www.trecord.org> ID Number: 6045, Acesso em: 3 de janeiro de 2016.

GLOTZER, R. The Influence of Carnegie Corporation and Teachers College, Columbia, in the Interwar Dominions: The Case for Decentralized Education. Historical Studies in Education/Revue d'histoire de l'éducation, [S.1.] v. 1, n. 1/2, p. 93-111, 2000.

HALPERN, S. M. The Institute of International Education: A History. 1969. 271 f. (Tese de Doutorado) - Columbia University. New York, 1969. 
KANDEL, I. L. The International Institute of Teachers College. Teachers College Record, New York, v. 24, n. 4, 1923, p. 336-373. Disponível em: <http://www.trecord.org> ID Number: 6054, Acesso em: 2 de maio de 2014.

KANDEL, I. L. 1924. Introduction. Educational Yearbook of the International Institute of Teachers College, New York, v. 1, n. 1, p. 0-0, 1924. Disponível em:

$<\mathrm{http}$ ://www.trecord.org> ID Number: 14634. Acesso em: 3 de julho de 2010.

MICKENBER, J. The New Generation and the New Russia: Modern Childhood as Collective Fantasy. American Quarterly, Baltimore, MD, v. 62, n. 1, p. 103-134, March 2010.

NULL, J. W. A Disciplined Progressive Educator: The Life and Career of William Chandler Bagley, 1874-1946. 2001. 504f. (Tese de doutorado) - The University of Texas at Austin, August 2001.

NULL, J. W. William C. Bagley and the Founding of Essentialism: An Untold Story in American Educational History. Teachers College Record, New York, v. 109, n. 4, p. 10131055, April 2007b. Disponível em: <http://www.tcrecord.org> ID Number: 12868. Acesso em: 7 de fevereiro de 2016.

NULL, J. W. An Introduction to Isaac Leon Kandel: Who He Was and Why He Matters. The Educational Forum, [S.1.], v. 71, n. 2, p. 142-156, 2007a.

POLLACK, E. Isaac Leon Kandel (1881-1965). UNESCO: International Bureau of Education, Paris, v. 23, n. 3/4, p. 775-787, 1993.

RUSSELL, J. E. Education for Democracy. Teachers College Record, New York, v. 19, n. 3, p. 219-228, 1918. Disponível em: <http://www.trecord.org> ID Number: 3589, Acesso em: 2 de dezembro de 2014.

RUSSELL, W. F. Merchants of Light: a statement of the purposes and aims of the International Institute of Teachers College, Columbia University. [A paper read before the General Meeting of the Teachers College Alumni Conferences, April 25, 1924]. Teachers College Record, New York, v. 26, n. 1, p. 13-21, 1924. Disponível em:

$<$ http://www.trecord.org> ID Number: 11924, Acesso em: 5 de março de 2014.

TEACHERS COLLEGE. Announcement of the School of Education. New York: Teachers College, 1924, p. 30-32.

TEACHERS COLLEGE. Documentos dos alunos de 1928/1929. Special Collections. Teachers College, New York. Acesso em: junho de 2002.

WARDE, M. J. Encantamentos e desencantamentos com a América: os Estados Unidos em escrita de Anísio Teixeira. Projeto História (PUCSP), São Paulo v. 32, p. 171-188, 2006.

WARDE, M. J. Intertwined and Parallel Stories of Educational History: Brazil and Turkey in the Early 20th Century. In: POPKEWITZ, T. S. (Org.). Rethinking the History of Education: Transnational Perspectives on its Questions, Methods, and Knowledge. New York: Palgrave Macmillan, 2013, p. 109-13. http://dx.doi.org/10.1057/9781137000705_6 